STUDIA Z PRAWA WYZNANIOWEGO

Tom $24-2021$

DOI: https://doi.org/10.31743/spw.12310

\title{
RZĄDOWY PROJEKT USTAWY O RATYFIKACJI KONKORDATU MIĘDZY STOLICĄ APOSTOLSKĄ I RZECZĄPOSPOLITĄ POLSKĄ W OBRADACH SEJMOWEJ KOMISJI SPRAW ZAGRANICZNYCH Z 16 GRUDNIA 1997 R.
}

The government's draft law on the ratification of the Concordat between the Holy See and the Republic of Poland at the sitting of the Sejm Committee for Foreign Affairs of December 16, 1997

Streszczenie: Podpisanie w dniu 28 lipca 1993 r. Konkordatu między Stolicą Apostolską a Rzecząpospolitą Polską było ważnym wydarzeniem w najnowszej historii wzajemnych stosunków Państwa polskiego i Kościoła Katolickiego. Spory polityczne sprawiły jednak, że proces ratyfikacji tej umowy międzynarodowej znacząco przeciągnął się w czasie. W niniejszym opracowaniu przedstawiony został jeden $\mathrm{z}$ elementów tego procesu, a mianowicie debata przeprowadzona $\mathrm{w}$ trakcie obrad sejmowej Komisji Spraw Zagranicznych, jaka odbyła się 16 grudnia 1997 r. W jej trakcie poruszone zostały kwestie dotyczące trybu uchwalenia ustawy ratyfikacyjnej oraz włączenia do niej deklaracji interpretacyjnej Rządu RP z dnia 15 kwietnia 1997 r. W wyniku prac Komisji do Sejmu skierowany został projekt ustawy ratyfikacyjnej, którą uchwalono 8 stycznia 1998 r. Ratyfikacja Konkordatu nastąpiła w dniu 23 lutego $1998 \mathrm{r}$.

Slowa kluczowe: Konkordat z 1993 r.; Konstytucja RP; ustawa ratyfikacyjna; Sejm RP; Komisja Spraw Zagranicznych; ratyfikacja umowy międzynarodowej

Abstract: The conclusion of the Concordat between the Holy See and the Republic of Poland on July 28, 1993 was undoubtedly an important event in the recent history of the mutual relations between the Polish state and the Catholic Church.

* Ks. prof. dr hab., Zakład Kościelnego Prawa Rodzinnego, Wydział Prawa Kanonicznego, Uniwersytet Kardynała Stefana Wyszyńskiego, ul. Dewajtis 5, 01-815 Warszawa, e-mail:w_goralski@wp.pl. ORCID 0000-0001-6548-4120. 
However, due to the political disputes, the process of ratification of this international agreement was significantly delayed. The present paper discusses one element of this process, that is, the debate that was held at the sitting of the Sejm Committee for Foreign Affairs on 16 December, 1997. The debate concerned, among other things, the legislative procedure for ratification of the Concordat and the issue of including the Government's interpretive declaration of 15 April, 1997 in the ratification act. As a result of the work undertaken by the Committee, the draft ratification act was submitted to the Sejm and subsequently adopted on 8 January, 1998. The Concordat was ratified on 23 February, 1998.

Key words: Concordat of 1993; Constitution of the Republic of Poland; ratification act; Sejm of the Republic of Poland; Committee for Foreign Affairs; ratification of an international agreement

\section{WPROWADZENIE}

Podpisanie w dniu 28 lipca 1993 r. Konkordatu między Stolicą Apostolską i Rzecząpospolitą Polską ${ }^{1}$ stanowiło niewątpliwie doniosłe wydarzenie w najnowszej historii wzajemnych relacji Państwa polskiego i Kościoła Katolickiego. Umowa ta przełamała bowiem niechlubny okres, który nastąpił po 12 września 1945 r. (zerwanie przez Tymczasowy Rząd Jedności Narodowej Konkordatu z 10 lutego 1925 r.)², kiedy to owe relacje znamionowała regulacja wyłącznie ustawowa, a więc jednostronna.

Konkordat z 28 lipca 1993 r. jako pierwsza tego typu umowa zawarta przez Stolicę Apostolską z państwem postkomunistycznym Europy Środkowo-Wschodniej, stanowił adekwatny instrument prawny służący uregulowaniu głęboko rozchwianych po 1945 r. wzajemnych relacji Państwa polskiego i Kościoła Katolickiego. Instrument ten pośrednio przyczynił się także do unormowania stosunków między Państwem a innymi kościołami i związkami wyznaniowymi.

Istotne znaczenie tej umowy międzynarodowej niewątpliwie tkwi w konsekwencjach dotyczących przede wszystkim społeczeństwa polskiego, kładzie ona bowiem kres tymczasowości, a także regulacji jednostronnej

1 Konkordat między Stolicą Apostolską i Rzecząpospolitą Polską podpisany dnia 28 lipca 1993 r., Dz. U. z 1998 r. Nr 51, poz. 318.

2 Zob. Krukowski 2000, 233. 
wzajemnych odniesień dwóch wspólnot (religijnej i politycznej), naznaczonej w praktyce dotkliwym dla tegoż społeczeństwa rysem separacji wrogiej.

Po latach drastycznego, systematycznego ograniczania wolności Kościoła, w nowej rzeczywistości politycznej, jaka zaistniała w kraju po 1989 r., można było realnie myśleć o umowie konkordatowej ze Stolicą Apostolską. Już 25 października 1991 r. strona kościelna przedstawiła stronie rządowej projekt takiego traktatu (strona rządowa przekazała stronie kościelnej swój projekt dopiero 12 marca 1993 r.). Po uzgodnieniu w dniu 28 maja 1993 r. przez układające się strony tekstu Konkordatu i przyjęciu go przez Radę Ministrów (1 czerwca tego samego roku) oraz upoważnieniu przez nią Ministra Spraw Zagranicznych Krzysztofa Skubiszewskiego do podpisania umowy, 28 lipca 1993 r. doszło do jej zawarcia; pozostało jedynie przeprowadzenie procedury ratyfikacyjnej ${ }^{3}$.

Już wkrótce po podpisaniu umowy i opublikowaniu jej tekstu pojawiły się wobec niej liczne zastrzeżenia, wysuwane głównie przez środowiska nieprzychylne Kościołowi, szczególnie po 19 września 1993 r., kiedy to w wyborach parlamentarnych zwyciężył Sojusz Lewicy Demokratycznej, który - w koalicji z Polskim Stronnictwem Ludowym - zdobył większość parlamentarną ${ }^{4}$. Jak się okazało, rozpoczęty 8 marca 1994 r. przez przyjęcie przez Radę Ministrów projektu ustawy ratyfikacyjnej proces ratyfikacji Konkordatu napotkał na silny opór ze strony większości parlamentarnej. Sprawiło to, że projekt ten, skierowany przez rząd Waldemara Pawlaka w dniu 17 marca 1994 r. do Sejmu, praktycznie został na kilka lat „zamrożony”.

Meandryczna droga prowadząca do ratyfikacji Konkordatu naznaczona była coraz to nowymi, często irracjonalnymi zarzutami (np. niezgodności niektórych przepisów umowy z przyszłą konstytucją), zmierzającymi do notorycznego odkładania uchwalenia ustawy ratyfikacyjnej ad calendas graecas, nawet po wejściu w życie (17 kwietnia 1997 r.) Konstytucji RP5, gdy okazało się, że Konkordat jest w pełni zgodny z jej postanowieniami.

Góralski 1998a, 19-21.

4 Krukowski 1999, 53-57.

5 Konstytucja Rzeczypospolitej Polskiej z dnia 2 kwietnia 1997 r., Dz. U. z 1997 r. $\mathrm{Nr} 78$, poz. 483 z późn. zm. 
Nieprzychylny traktatowi klimat polityczny zmienił się dopiero po wyborach parlamentarnych z 21 września 1997 r., które przyniosły zwycięstwo Akcji Wyborczej Solidarność. Miesiąc później, 20 października, nowo wybrany Marszałek Sejmu Maciej Płażyński wyraził przekonanie, że w nowej konstelacji politycznej nie powinno być trudności z ratyfikacją Konkordatu 6 . W dniu 7 listopada 1997 r. Rada Ministrów kierowana przez premiera Jerzego Buzka przyjęła nowy projekt ustawy ratyfikacyjnej, przekazując go do Sejmu?

Po wydaniu 10 grudnia 1997 r. przez kierownictwo Socjaldemokracji Rzeczypospolitej Polskiej oświadczenia o głosowaniu w Sejmie za odrzuceniem projektu ustawy upoważniającej prezydenta RP do ratyfikowania traktatu, dwa dni później (12 grudnia), podczas pierwszego czytania w Sejmie tegoż projektu, po nieudanej próbie SLD odrzucenia go, projekt ten skierowano do sejmowej Komisji Spraw Zagranicznych ${ }^{8}$.

Podczas posiedzenia, odbytego 16 grudnia 1997 r., wymieniona Komi$\mathrm{sja}^{9}$, po długiej debacie przyjęła projekt ustawy ratyfikacyjnej, kierując go do Sejmu ${ }^{10}$. Przedmiotem debaty były dwie podstawowe kwestie, dotyczące trybu uchwalenia ustawy ratyfikacyjnej oraz włączenia do tejże ustawy Deklaracji rządu premiera Włodzimierza Cimoszewicza z dnia 15 kwietnia 1997 r., wyjaśniającej niektóre regulacje konkordatowe.

Zaprezentowanie w niniejszym artykule debaty sejmowej Komisji Spraw Zagranicznych nad projektem ustawy ratyfikacyjnej ma stanowić

6 Góralski 1998a, 135.

7 Tamże, 138.

8 Tamże, 187.

9 W obradach sejmowej Komisji Spraw Zagranicznych uczestniczyli posłowie: Czesław Bielecki (AWS) - przewodniczący, Franciszek Adamczyk (AWS), Piotr Ikonowicz (SLD), Tadeusz Iwiński (SLD), Antoni Kobielusz (SLD), Włodzimierz Konarski (SLD), Olga Krzyżanowska (UW), Teresa Lipowicz (UW), Tadeusz Mazowiecki (UW), Leszek Miller (SLD), Stefan Niesiołowski (AWS), Józef Oleksy (SLD), Longin Pastusiak (SLD), Grzegorz Piechowiak (AWS), Marian Piłka (AWS), Marian Sołtysiewicz (AWS), Mirosław Styczeń (AWS), Tomasz Wójcik (AWS), Kosma Złotowski (AWS), a także Janusz Stańczyk, podsekretarz stanu w Ministerstwie Spraw Zagranicznych. Biuletyn nr 119/III, 1, http://orka. sejm.gov.pl?Biuletyn.nsf/0/D37FC24C0A91EE45C1256B7300038C972?OpenDokument [dostęp: 20.02.2021].

10 Góralski 1998a, 143-144; Góralski 1998b, 20. 
przyczynek do pełniejszego poznania złożonej i trwającej ponad cztery lata historii procedury ratyfikacyjnej umowy konkordatowej.

\section{KWESTIA TRYBU UCHWALENIA USTAWY RATYFIKACYJNEJ}

Skierowanie 7 listopada 1997 r. przez rząd premiera Jerzego Buzka do Sejmu RP projektu ustawy upoważniającej prezydenta RP do ratyfikowania Konkordatu ze Stolicą Apostolską było praktycznie wdrożeniem nowej procedury ratyfikacyjnej, rozpoczętej z inicjatywy rządu Waldemara Pawlaka, blokowanej przez Sejm II kadencji.

Argumentem wysuwanym przez lewicę za odłożeniem ratyfikacji było uporczywie podtrzymywane twierdzenie, iż akt ten powinien się dokonać w trybie art. 90 ust. 1 i 2 nowej Konstytucji (z dnia 2 kwietnia 1997 r.), gdyż umowa międzynarodowa, na podstawie której Rzeczpospolita Polska ma „przekazać organizacji międzynarodowej lub organowi międzynarodowemu kompetencje organów władzy państwowej w niektórych sprawach” (ust. 1) wymaga do ratyfikacji (w Sejmie), „większości 2/3 głosów w obecności co najmniej połowy ustawowej liczby posłów" oraz (w Senacie) „większości 2/3 głosów w obecności co najmniej połowy ustawowej liczby senatorów" (ust. 2). Uznano więc najpierw, że Kościół Katolicki jest organizacją międzynarodową lub organem międzynarodowym, a następnie że Państwo polskie przekazuje tej „organizacji/organowi” część kompetencji własnych organów ${ }^{11}$.

Tego rodzaju bezpodstawne twierdzenia prostował - podczas pierwszego czytania w Izbie Niższej parlamentu (12 grudnia 1997 r.) - Bronisław Geremek, ówczesny Minister Spraw Zagranicznych ${ }^{12}$.

Owa teza głoszona przez lewicę została następnie forsowana podczas posiedzenia sejmowej Komisji Spraw Zagranicznych w dniu 16 grudnia 1997 r. Wątek ten podjął poseł Tadeusz Iwiński (SLD) stwierdzając, że poza ekspertyzami dotyczącymi „stanu zgodności Konkordatu z Konstytucją i ustawami” przedłożonymi posłom przez Marszałka Sejmu Macieja Płażyńskiego, Klub SLD dysponuje również zamówionymi przez siebie

11 Góralski 1998a, 140.

12 Tamże, 141-142. 
czterema ekspertyzami (m.in. prof. Andrzeja Wiesława Langa z UMK), których konkluzje są odmienne w stosunku do konkluzji tych pierwszych, gdy chodzi o tryb, w jakim Konkordat powinien być ratyfikowany - zgodnie $\mathrm{z}$ art. 90 Konstytucji $\mathrm{RP}^{13}$.

Przewodniczący obradującej Komisji zapowiedział, że owe ekspertyzy, które otrzyma od posła T. Iwińskiego, prześle członkom tejże Komisji jeszcze podczas trwającego posiedzenia. Poseł Irena Lipowicz (UW) oznajmiła wówczas, że nie ma potrzeby przyjmowania nowych ekspertyz, gdyż „Wszystkie możliwe ekspertyzy w tej sprawie są już powszechnie znane"14. Podobną opinię wypowiedział poseł Kosma Złotowski (AWS) wnioskując jednocześnie o zamknięcie dyskusji, czemu przeciwna była Irena Lipowicz uznając, że tego rodzaju zabiegi (zamykania dyskusji przed jej rozpoczęciem) stosowano w Sejmie poprzedniej kadencji (1993-1997). Przeciwko ograniczaniu prawa posłów do wypowiadania się opowiedzieli się także posłowie SLD: Longin Pastusiak i Józef Oleksy ${ }^{15}$.

Po wycofaniu swojego wniosku przez Kosmę Złotowskiego (powołał się na apel Ireny Lipowicz), przewodniczący obrad otworzył debatę na temat rządowego projektu ustawy o ratyfikacji Konkordatu ${ }^{16}$.

Wracając do swojej informacji o czterech ekspertyzach wskazujących na konieczność uwzględnienia w procedurze ratyfikacyjnej umowy konkordatowej art. 90 Ustawy zasadniczej, Tadeusz Iwiński uznał, że podczas odbywającego się posiedzenia nie widzi możliwości głosowania nad wnioskiem o przyjęciu projektu ustawy ratyfikacyjnej ${ }^{17}$. Przewodniczący obrad zapewnił posła, że - jak już to powiedział - owe ekspertyzy zostaną doręczone członkom Komisji jeszcze w czasie odbywających się obrad. Poseł Olga Krzyżanowska (UW) wyraziła przekonanie o konieczności zapoznania się członków Komisji z tymi opiniami, podkreślając jednocześnie, że nie należy występować o kolejne, ,gdyż jest to po prostu strata czasu”; apelowała przy tym o unikanie przez posłów „,W stosunku do siebie różnych określeń i złośliwości”, gdyż może to utrudnić głosowanie nad sprawą ${ }^{18}$.

\footnotetext{
13 Zob. Wisłocki 1993, 184.

14 Biuletyn nr 119/III, 2.

15 Tamże, 2-3.

16 Tamże, 3.

17 Tamże, 4.

18 Tamże.
} 
Z kolei poseł Tomasz Wójcik (AWS) zwrócił się do wiceministra Janusza Stańczyka (jako prawnika) o opinię w sprawie trybu przyjmowania ustawy o ratyfikacji Konkordatu: czy podstawą winien tu być art. 89 czy art. 90 Konstytucji RP.

Wymieniony podsekretarz stanu w MSZ stwierdził na wstępie, że pytanie to jest efektem ,zamieszania myślowego wokół charakteru prawnego Stolicy Apostolskiej i jej statusu prawno-międzynarodowego"19. W nieodległym czasie, przyznał, pojawił się pogląd, ,sygnowany tylko jednym nazwiskiem" dotyczący konieczności zastosowania specjalnego trybu przyjęcia Konkordatu na mocy art. 90 Konstytucji RP, który to artykuł znajduje swoją aplikację w sytuacji, w której chodzi o przekazanie kompetencji państwowych danej organizacji międzynarodowej lub organowi międzynarodowemu. Minister J. Stańczyk stwierdził, że w doktrynie prawa międzynarodowego i w praktyce międzynarodowej sprawą bezdyskusyjną jest to, że „Stolica Apostolska nie posiada statusu organizacji międzynarodowej ani organu międzynarodowego", w związku z czym powołany artykuł Ustawy zasadniczej „nie może mieć zastosowania w przypadku Konkordatu”20. Przypomniał też, że status prawny Stolicy Apostolskiej uprzedza powstanie pojęcia organizacji międzynarodowej (charakter prawny i możliwość prawno-międzynarodowej podmiotowości organizacji międzynarodowej wywodzi się z orzecznictwa Trybunału Sprawiedliwości w Hadze z przełomu lat 40. i 50. XX w., jest to więc sprawa nowa ${ }^{21}$.

Janusz Stańczyk stwierdził następnie, że nikt nie kwestionuje ius contrahendi $i^{22}$, czyli prawa Stolicy Apostolskiej do zawierania umów międzynarodowych ani prawa legacji (biernej i czynnej), a więc utrzymywania stosunków dyplomatycznych (ius legationis), i to na długo przed połową XX stulecia. Stolica Apostolska występuje także jako strona traktatów międzynarodowych, których stronami mogą być tylko państwa; jest również „uczestnikiem wielu organizacji międzynarodowych otwartych tylko dla państw, w tym Organizacji Narodów Zjednoczonych". Elementy te przesądzają o tym, dodał J. Stańczyk, że prawno-międzynarodowy status

19 Tamże.

20 Tamże. Zob. Krukowski 2000, 149; zob. także Olejarz 2009, 67-94.

21 Biuletyn nr 119/III, 5.

22 W stenogramie podano błędnie: ,jus contrahenti”. Tamże. 
Stolicy Apostolskiej „zbliżony jest do państwowego" ${ }^{23}$. Trafna była też uwaga, w myśl której „doktryna posługuje się pojęciem specyficznego określenia prawno-międzynarodowej podmiotowości Stolicy Apostolskiej, zbliżając się jednak do statusu państwa"24.

Wiceminister stwierdził ponadto, że sprawa wybitności autorytetów w dziedzinie doktryny prawa jest względna, wybitność bowiem jest pojęciem ulotnym i niejednokrotnie ograniczonym do ,samoidentyfikacji osoby zainteresowanej”, czasem także wąskiego środowiska. Minimum wybitności, dodał, to przejście red face test, czyli ,nieczerwienienie się przy wypowiadaniu własnych opinii”. Padły następnie dosadne słowa: „Jestem przekonany, że ktoś, kto utrzymuje, iż organizacja apostolska jest organizacją bądź organem międzynarodowym, musiałby się czerwienić" ${ }^{25}$.

Po wystąpieniu ministra Janusza Stańczyka do tematu trybu uchwalenia ustawy ratyfikacyjnej już nie wrócono. Oznaczało to, że ustawa ta powinna być uchwalona w trybie art. 89 Konstytucji RP.

Tym samym posłowie lewicy nie podnosili już kwestii przekazania w Konkordacie przez Państwo polskie Kościołowi Katolickiemu - jak to twierdzili - kompetencji organów władzy państwowej w niektórych sprawach (art. 90 ust. 1 Konstytucji RP). To przekazanie kompetencji Kościołowi miało dotyczyć małżeństwa „konkordatowego” (art. 10) oraz spraw finansowych, instytucji i dóbr kościelnych oraz duchowieństwa (art. 22 ust. 2 Konkordatu).

Należy dodać, że na wstępie debaty nad kolejną sprawą (włączenie Deklaracji Rządu RP z dnia 15 kwietnia 1997 r. $^{26}$ do ustawy ratyfikacyjnej) poseł Tadeusz Mazowiecki (UW) wypowiedział się jeszcze w sprawie trybu uchwalenia ustawy ratyfikacyjnej, polemizując z Tadeuszem Iwińskim, który lansował konieczność zastosowania tutaj art. 90 Konstytucji RP. Poseł Unii Wolności przypomniał, że poseł T. Iwiński brał udział w pracach Komisji Konstytucyjnej i na pewno dobrze pamięta, o co chodzi

23 Tamże.

24 Tamże.

25 Tamże.

26 Oświadczenie Rządowe z dnia 26 stycznia 1998 r. w sprawie Deklaracji Rządu Rzeczypospolitej Polskiej z dnia 15 kwietnia 1997 r. w celu zapewnienia jasnej wykładni przepisów Konkordatu między Stolicą Apostolską a Rzecząpospolitą Polską, podpisanego w Warszawie w dniu 28 lipca 1993 r., M.P. z 1998 r. Nr 4, poz. 51, dalej: Deklaracja Rządu RP. 
w art. 90 Konstytucji RP, a o co w art. 25 ust. 4, który wyraźnie stanowi, że stosunki między Rzecząpospolitą Polską a Kościołem Katolickim reguluje umowa międzynarodowa zawarta ze Stolicą Apostolską i ustawy; nie było intencją ustawodawcy, by „przewidywać tę samą regulację w dwóch artykułach". Tadeusz Mazowiecki wyraził przy tym przekonanie, że posłowie SLD uprawiają tutaj „slalom argumentów: raz chcą podpisać Konkordat, a drugi raz nie chcą”. I dodał: „Skończcie panowie z tym slalomem. Kiedy jesteście w rządzie, mówicie że chcecie ratyfikować Konkordat. Na Sali sejmowej mówicie, że jesteście przeciwni. Powoływanie się na art. 90 Konstytucji jest kolejnym argumentem dowodzącym uprawiania tego slalomu" 27 . Poseł Iwiński odpowiedział, że nigdy publicznie nie opowiadał się za ratyfikowaniem Konkordatu w trybie art. 90 Konstytucji RP, przytaczał jedynie opinie wielu znanych prawników, i że klub SLD dysponuje takimi ekspertyzami ${ }^{28}$.

„Nie widzę w Konkordacie niczego, co Polska cedowałaby na Stolicę Apostolską", oświadczył bp Tadeusz Pieronek, ówczesny sekretarz generalny Konferencji Episkopatu Polski i jeden z negocjatorów wymienionej umowy ${ }^{29}$.

\section{PROBLEM WŁACCZENIA DO USTAWY RATYFIKACYJNEJ DEKLARACJI RZĄDU RP Z DNIA 15 KWIETNIA 1997 R.}

Debatę nad drugą kwestią poruszoną podczas posiedzenia Komisji, dotyczącą włączenia do ustawy ratyfikacyjnej Deklaracji rządu Włodzimierza Cimoszewicza wyjaśniającej wątpliwości strony państwowej co do niektórych postanowień Konkordatu ${ }^{30}$, rozpoczął poseł Tadeusz Iwiński

27 Tamże, 6.

28 Tamże.

29 Góralski 1998a, 141.

30 Deklaracja Rządu RP brzmiała następująco: ,W celu zapewnienia jasnej wykładni przepisów Konkordatu między Stolicą Apostolską i Rzecząpospolitą Polską, podpisanego dnia 28 lipca 1993 r., zwanego dalej «Konkordatem», Rząd Rzeczypospolitej Polskiej, w uzgodnieniu ze Stolicą Apostolską, oświadcza, co następuje:

1. Zasada wyrażona w artykule 1, według której Państwo i Kościół są niezależne i autonomiczne, jest w istocie nadaniem wyrazu prawnego praktyce, jaka wytworzyła się w Polsce 
(SLD) zgłaszając formalny wniosek, by w art. 1 projektu ustawy o ratyfikacji Konkordatu między Stolicą Apostolską i Rzecząpospolitą Polską: „Wyraża się zgodę na dokonanie przez Prezydenta RP ratyfikacji Konkordatu między Stolicą Apostolską i Rzecząpospolitą Polską sporządzonego w Warszawie w dniu 28 lipca 1993 r.”, zamiast kropki postawić przecinek i dodać wyrazy: ,tak jak jest on rozumiany w świetle deklaracji rządu Rzeczypospolitej Polskiej z dnia 15 kwietnia 1997 r. zawierającej oświadcze-

na przestrzeni ostatnich lat. Oznacza ona rezygnację z takiego pojmowania norm konstytucyjnych, które wyrażało stosunek antagonistyczny, na rzecz wykładni zakładającej współdziałanie dla rozwoju człowieka i dobra wspólnego.

2. Pojęcie nienaruszalności cmentarzy, użyte w artykule 8 ust. 3 Konkordatu, nie może być rozumiane jako prawo do odmowy pochowania na cmentarzu katolickim osoby innego wyznania lub niewierzącej.

3. Konkordat szanuje całkowitą wolność nupturientów co do tego, jakie zawrą małżeństwo i na jakim forum ma ono wywierać skutki. Konkordat pozostawia sprawę realizacji zasad określonych w artykule 10 ustawodawstwu polskiemu.

4. Konkordat w artykule 12 stanowi, że:

a) organizowanie nauki religii katolickiej odbywać się będzie z poszanowaniem zasady tolerancji i wolności religijnej. Państwo gwarantuje organizowanie nauki religii w szkołach i przedszkolach publicznych wówczas, gdy osoby zainteresowane wyrażą taką wolę w sposób określony w prawie polskim,

b) uczestniczenie w katechezie w szkołach i przedszkolach publicznych jest dobrowolne, czyli bez przymusu i ograniczania,

c) sprawy związane z zatrudnianiem i wynagradzaniem katechetów, należące do dziedziny stosunków pracy, ureguluje ustawa.

5. Konkordat w artykule 17 potwierdza prawo gwarantowane przez Państwo do:

a) dobrowolnego korzystania z posługi duszpasterskiej w zakładach penitencjarnych,

b) dobrowolnego korzystania z posługi kapelanów w zakładach opieki zdrowotnej i społecznej.

6. Konkordat uznaje określone ustawodawstwem polskim kompetencje organów państwowych do regulowania kwestii finansowych i podatkowych kościelnych osób prawnych i fizycznych. W tym celu strona państwowa zapozna się z opinią strony kościelnej w łonie odpowiedniej Komisji, o której mowa w artykule 22 ust. 2 i 3.

7. Zasady wyrażone w artykule 27 i 28 Konkordatu będą stosowane przy poszanowaniu konstytucyjnie określonych kompetencji Rządu Rzeczypospolitej Polskiej oraz poszanowaniu kompetencji Stolicy Apostolskiej i Konferencji Episkopatu Polski”. Komentarz do Deklaracji Rządu RP zob. Góralski 1998a, 105-109. 
nie, w celu zapewnienia jasnej wykładni przepisów Konkordatu, załączonej do niniejszej ustawy"31.

Zgłaszając ten wniosek, poseł lewicy wypowiedział jednocześnie krótki komentarz. Przypomniał w nim Deklarację rządu Włodzimierza Cimoszewicza sprzed ośmiu miesięcy - wprawdzie jednostronną, lecz sporządzoną po konsultacjach ze Stolicą Apostolską. Dokument ten - podkreślił poseł - „daje wykładnię niektórych artykułów Konkordatu, m.in. zasady niezależności i autonomii (art. 1), rozwiewa wiele wątpliwości, zwłaszcza dotyczące chowania zmarłych na cmentarzach katolickich, sakramentu małżeństwa czy nauki religii w szkołach i przedszkolach publicznych, spraw finansowych Kościoła czy korzystania z posług religijnych”. Jednocześnie wnioskodawca podkreślił, że odwołanie się w ustawie do owej Deklaracji „rozwiewałoby ostatecznie większość wątpliwości”32.

Poproszony przez przewodniczącego o wypowiedź, Janusz Stańczyk stwierdził, że Deklaracja Rządu RP stanowi wyraz troski ostatnich dwóch ministrów spraw zagranicznych (Władysława Bartoszewskiego i Dariusza Rosatiego) o wyjaśnienie wątpliwości podnoszonych podczas publicznej debaty „okołokonkordatowej”33. Niezależnie od tego, czy wątpliwości były uzasadnione czy nie, a także czy przepisy Deklaracji Rządu RP rozjaśniają i usuwają pozorne sprzeczności i niedopowiedzenia umowy dwustronnej czy też są tylko parafrazą odpowiednich postanowień Konkordatu, Deklaracja „niczego nie ujmuje i niczego nie dodaje” ${ }^{34}$. Być może, dodał J. Stańczyk, Deklaracja Rządu RP sformułowana jest w takim języku, który budzi kolejne wątpliwości. Przypomniał też, że w stosunku do Deklaracji padały słowa krytyczne także po tej stronie, która wcześniej się jej domagała. Uznał, że jest to problem „bardzo złożony” i wyraził przypuszczenie, że proces interpretacji nie kończy się na Deklaracji. Nie zgodził się też ze stwierdzeniem T. Iwińskiego, iż minister Bronisław Geremek wysoko ocenił ten dokument, a jeśli tak było, to „bardziej chodziło o tryb niż treść"35.

\footnotetext{
31 Biuletyn nr 119/III, 5.

32 Tamże.

33 Zob. Rokita 1998, 52-55.

34 Biuletyn nr 119/III, 5.

35 Tamże, 6.
} 
Podsekretarz stanu przyznał, że choć dokument jest formalnie jednostronny, to ma za sobą uzgodnienie z drugą stroną i nie ma powodu, by z niego rezygnować. Wyjaśnił przy tym, że od początku owych uzgodnień była jasność po obu stronach co do formuły prawnej Deklaracji Rządu RP, która to formuła pozostaje niezmienna, stosownie do art. 31 ust. 2b Konwencji Wiedeńskiej o prawie traktatów z 1969 r. ${ }^{36}$ (odsyła Deklarację do kontekstu Konkordatu). J. Stańczyk jednoznacznie też stwierdził, że nigdy nie było próby uczynienia z tego dokumentu załącznika stanowiącego część Konkordatu; nie było też na to zgody drugiej strony ${ }^{37}$.

„Przy takim rozumieniu, kontynuuje swój wywód podsekretarz stanu w MSZ, propozycja rządu premiera Cimoszewicza przedstawiona w autopoprawce była dziwną hybrydą prawną. Jedno nie zgadzało się z drugim. Nie było tu spójności prawnej. Rząd premiera Buzka, minister spraw zagranicznych wychodzi ze ściśle legalistycznego punktu widzenia. Przywraca i nadaje Deklaracji to znaczenie prawne, jakie miała mieć od samego początku. Nic więcej i nic mniej. Takie jest stanowisko rządu"38.

Po tym wyjaśnieniu minister J. Stańczyk oświadczył, iż nie ma żadnej potrzeby modyfikacji projektu ustawy o ratyfikacji Konkordatu. Deklaracja Rządu RP pozostaje zasadniczo dokumentem prawno-międzynarodowym, a jej status jest regulowany prawem międzynarodowym (zgodnie z Konwencją Wiedeńską o prawie traktatów przyjętą do polskiego porządku prawnego, zachowuje swoją moc na podstawie powołanego już art. 31 ust. 2 b) ${ }^{39}$.

Janusz Stańczyk zapewnił następnie uczestników posiedzenia, iż Deklaracja Rządu RP będzie respektowana przez rząd, zgodnie z art. 9 Ustawy zasadniczej (poszanowanie dla prawa międzynarodowego) i w tej formule będzie traktowana (minister Bronisław Geremek zapowiedział jej publikację w trybie urzędowym) i odpowiedział na kolejne argumenty rzeczników opinii, w myśl której Deklaracja Rządu RP powinna być dokumentem towarzyszącym wykładni Konkordatu, na który można by się

36 Konwencja Wiedeńska o prawie traktatów sporządzona w Wiedniu dnia 23 maja 1969 r., Dz. U. z 1990 r. Nr 74, poz. 439.

37 Biuletyn nr 119/III, 7.

38 Tamże.

39 Tamże. 
powoływać w praktycznym stosowaniu umowy. Każdy obywatel, dodał minister J. Stańczyk, będzie miał okazję do zapoznania się z pełną treścią Deklaracji Rządu RP ,i powoływania się na to, co Deklaracja dla jednych wyjaśnia w konkordacie, a co dla drugich powtarza"40.

Po tym wyjaśnieniu podsekretarza stanu głos zabrał poseł Włodzimierz Konarski (SLD), apelując o poszukiwanie porozumienia w rozpatrywanej kwestii. Zwrócił uwagę, że gdy Konkordat wejdzie w życie, sądy, interpretując jego postanowienia będą musiały sięgać do treści Deklaracji rządowej uzgodnionej i zaakceptowanej przez Stolicę Apostolską. Aby sądy mogły odwoływać się do precyzyjnej interpretacji Konkordatu, w ustawie ratyfikacyjnej należy wspomnieć, że interpretacja tej umowy dwustronnej będzie dokonywana ,w zgodzie z deklaracją rządową, na którą zgodziła się Stolica Apostolska"41.

Optując zdecydowanie za dołączeniem do ustawy ratyfikacyjnej Deklaracji rządowej, poseł zarzucił Ministerstwu Spraw Zagranicznych pominięcie wzmianki o tym dokumencie w uzasadnieniu ustawy o ratyfikacji Konkordatu, co - w trybie ad vocem - skorygował przewodniczący Komisji oraz poseł Olga Krzyżanowska (UW) ${ }^{42}$.

Przeciw dołączeniu Deklaracji Rządu RP do ustawy ratyfikacyjnej wypowiedział się poseł Tomasz Wójcik (AWS), motywując to koniecznością uzyskania podpisu pod tym dokumentem również ze strony Stolicy Apostolskiej, tymczasem jest to dokument jednostronny, niemający żadnego związku z ustawą ratyfikacyjną ${ }^{43}$.

Poseł Longin Pastusiak (SLD), odpowiadając posłowi T. Wójcikowi stwierdził, że istnieje bardzo szeroko stosowana praktyka międzynarodowa dołączania do tekstów umowy dwustronnej protokołów interpretacyjnych (m.in. w Konkordacie włoskim) ${ }^{44}$, choć nie stanowią one integralnej części umowy i nie wymagają podpisania przez drugą stronę. Wyraził przy tym zdziwienie, że rząd czyni krok wstecz, tym bardziej że na Deklarację Rządu RP zgodę wyraziła Stolica Apostolska, a Kościół Katolicki w Polsce

40 Tamże.

41 Tamże.

42 Tamże, 8.

43 Tamże.

44 Tamże; zob. Protokół uzupełniający (do Konkordatu Stolicy Apostolskiej i Republiki Włoskiej z 18 lutego 1984 roku), w: Włodarczyk 1986, 208-210. 
nie zgłaszał zastrzeżeń. Powołał się także na słowa ministra B. Geremka, który oświadczył, że Konkordat będzie interpretowany zgodnie z Deklaracją Rządu RP ${ }^{45}$.

Pytając, o jaki dziennik urzędowy chodzi ministrowi, poseł zaapelował o „odpowiedź merytoryczną”, gdyż argumenty posła T. Wójcika, że „opóźni to ratyfikację i że wymagane będzie podpisanie deklaracji przez drugą stronę, w ogóle nie istnieją"46.

Z kolei poseł Leszek Miller (SLD), odnosząc się do wypowiedzi Tadeusza Mazowieckiego podkreślił, że zastrzeżenia lewicy dotyczą konkretnych treści Konkordatu, a nie Konkordatu jako takiego. „Szkoda [nadmienił], że część naszych sejmowych partnerów nie chce tego zrozumieć. Nasze intencje są wypaczane przez sugestie, że nasze zastrzeżenia odnoszą się do Kościoła i religii”" ${ }^{4}$.

L. Miller poruszył następnie problem autopoprawki rządu premiera W. Cimoszewicza. Stwierdził, że minister J. Stańczyk nadmienił, iż Stolica Apostolska wyraziła zgodę na treść Deklaracji Rządu RP, po czym rząd premiera W. Cimoszewicza skierował ten dokument do Sejmu w postaci autopoprawki, z zamiarem uczynienia z niej integralnej części usta$w^{48}$ ratyfikacyjnej, a Stolica Apostolska nie złożyła wobec tego sprzeciwu. Niezrozumiały jest więc opór w stosunku do przyjęcia tego samego trybu przez rząd premiera Jerzego Buzka. Poza tym poseł pytał o to, gdzie Deklaracja zostanie opublikowana i na jakiej podstawie prawnej ${ }^{49}$.

Głos w debacie zabrał następnie Józef Oleksy (SLD), zwracając uwagę na niewłaściwe podejście rządu do lewicy (sugerowanie jej złej woli

45 Poseł Longin Pastusiak przytoczył (na podstawie stenogramu z posiedzenia Sejmu) następujące oświadczenie ministra Bronisława Geremka: „Deklaracja pozostaje dokumentem powstałym w związku z zawarciem Konkordatu i daje ona interpretacyjny kontekst dla traktatu, jakim jest Konkordat. Rząd ze względu na skutki prawne tej deklaracji, jej znaczenie jako dokumentu zawierającego dodatkowe gwarancje praw i wolności obywatelskich, zamierza opublikować treść deklaracji w Dzienniku Urzędowym w charakterze załącznika do oświadczenia ministra spraw zagranicznych, dotyczącego mocy obowiązującej Konkordatu". Biuletyn nr 119/III, 8.

46 Zob. tamże, 8-9.

47 Tamże, 9.

48 W tekście jest: ,uchwały”. Tamże.

49 Tamże. 
i kunktatorstwa), dawny premier rządu wyraził przekonanie, że najważniejsze pytanie dla uczestników odbywającej się debaty dotyczy włączenia do ustawy ratyfikacyjnej ,jednego zdania uznającego moc wiążącą tej jednostronnej deklaracji" ${ }^{50}$. Przypomniał także, że w poprzedniej kadencji sejmowej nie bez trudności przygotowano traktat między Polską i USA oraz między Polską i Niemcami; niektóre zapisy tych umów były dość długo dyskutowane. Także w sprawie Konkordatu ci, którzy są zwolennikami jego ratyfikowania bez żadnych uwag, powinni uwierzyć, ,że potrzebne są pewne elementy uznania zasadności zgłaszanych wątpliwości"51. Na szczególne zwrócenie uwagi zasługuje końcowe zdanie wypowiedzi Józefa Oleksego: „Stolica Apostolska nie wyrażając sprzeciwu na deklarację rządu polskiego pośrednio uznała, że warto coś w Konkordacie uściślić i wyjaśnić. Stąd przecież wzięła się sprawa ustaw okołokonkordatowych, do potrzeby których mało kto zgłaszał wątpliwości lub sprzeciw"52.

Poseł Mirosław Styczeń (AWS) uznał, że wniosku posła Tadeusza Iwińskiego (o włączenie Deklaracji Rządu RP do ustawy ratyfikacyjnej) nie należy przyjmować, tym bardziej że po wejściu w życie Konstytucji RP wszelkie wątpliwości zostały rozwiane, a projektu rządowego nie trzeba „upiększać”. Zresztą - dodał poseł - lewica miała wystarczająco dużo czasu, bo cztery lata, na ratyfikację Konkordatu ${ }^{53}$.

Po dziesięciominutowej przerwie przewodniczący Komisji wznowił obrady.

Poseł Tomasz Wójcik (AWS), zachęcając uczestników posiedzenia do podjęcia decyzji, odniósł się do argumentów posłów lewicy. Ich pytanie o powody, dla których nie należałoby włączyć Deklaracji Rządu RP do

50 Tamże.

51 Tamże.

52 Tamże. Gdy chodzi o ustawy tzw. okołokonkordatowe, 27 czerwca 1997 r. przyjęto trzy: 1) o finansowaniu Papieskiej Akademii Teologicznej w Krakowie z budżetu państwa, Dz. U. z 1997 r. Nr 103, poz. 650; 2) o zmianie ustawy o cmentarzach i chowaniu zmarłych, Dz. U. z 1997 r. Nr 126, poz. 805; 3) o zmianie ustawy o gwarancjach wolności sumienia i wyznania oraz niektórych innych ustaw, Dz. U. z 1997 r. Nr 59, poz. 375. Natomiast Sejm nie zdołał odrzucić veta Senatu w odniesieniu do dwóch pozostałych ustaw: 1) o zmianie ustawy o systemie oświaty; 2) o zmianie ustawy - Kodeks rodzinny i opiekuńczy oraz ustawy - Prawo o aktach stanu cywilnego. Zob. Góralski 1998a, 126-127, 131-132.

53 Biuletyn nr 119/III, 9-10. 
ustawy ratyfikacyjnej, odwrócił pytając o powody przemawiające za przyjęciem tego dokumentu do ustawy i odpowiedział, że takich powodów nie dostrzega. Przykład Włoch wysunięty przez Longina Pastusiaka uznał za niefortunny, Konkordat tego państwa był bowiem zawierany w zupełnie innym kontekście historycznym, kiedy to istniała konieczność „odwrócenia sposobu rozumienia funkcji Kościoła w stosunku do państwa"54.

Antoni Kobielusz (SLD) wyraził ubolewanie, że „obecna koalicja” stara się imputować lewicy ,prowadzenie dwuznacznej gry w sprawie Konkordatu”, tymczasem chodzi o „rozjaśnienie” wątpliwości przy pomocy Deklaracji Rządu RP oraz ustaw „okołokonkordatowych”" 55 . Uznał, że prawica robi wszystko, by lewica Konkordatu nie poparła. Dodał, że wprowadzenie Deklaracji do ustawy ratyfikacyjnej byłoby wskazane „także z tego powodu, że zgodnie z hierarchią źródeł prawa zawartą w nowej konstytucji, umowa międzynarodowa ma wyższą rangę niż zwykła ustawa. Jeżeli w ustawie ratyfikacyjnej będzie wprowadzona wprost deklaracja, do zawartych w niej interpretacji będzie się można odnosić przy szczegółowych regulacjach prawnych" 56 .

Za wręcz demagogiczne można uznać retoryczne pytania posła: „Czy chcecie państwo, żebyśmy byli przeciwni Konkordatowi? Może chcecie mieć możliwość używania w mediach argumentu, że Sojusz Lewicy Demokratycznej jest niereformowalny, że SLD nie chce zaakceptować żadnych zmian. Po prostu nie dajecie nam żadnych szans. Skoro deklaracja została wynegocjowana, co stoi na przeszkodzie, żeby przyjąć propozycję zgłoszoną przez posła Iwińskiego?"57. W podobnej kategorii należałoby traktować następujące słowa A. Kobielusza: „,...] pochodzę z województwa, w którym w wielu gminach mniejszości wyznaniowe nie są wcale mniejszościami. Zgłaszają one wiele wątpliwości do Konkordatu. Nie są to wcale opinie polityków. To są opinie zwykłych ludzi. Jeśli chcemy wyjść naprzeciw tym opiniom i coś wyjaśnić, proszę nam nie przypisywać złych intencji. Może rzeczywiście możemy wspólnie coś w tej sprawie zrobić" ${ }^{58}$.

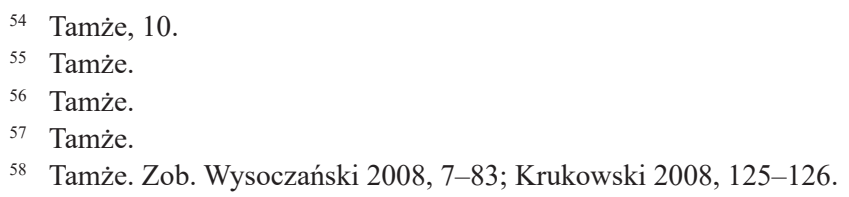


W wystąpieniu Piotra Ikonowicza (SLD) dało się wyczuć przekonanie, że poseł wie, iż Konkordat wkrótce będzie ratyfikowany. Niemniej jednak, jak sam powiedział, „opozycja jest potrzebna nie tylko po to, by kiedyś znowu weszła do koalicji rządowej, ale również po to, żeby sygnalizowała wolę, obawy i życzenia tej części elektoratu, która znalazła się w mniejszości po wyborach. Taką rolę powinniśmy starać się wypełnić do końca"59.

Zdziwienie mogło budzić stwierdzenie posła, iż „deklaracja rządu premiera Cimoszewicza tylko nieznacznie [podkreśl. W.G.] rozwiewa wątpliwości i poprawia sytuację" ${ }^{60}$. Zdaniem P. Ikonowicza, odmowa włączenia Deklaracji Rządu RP do ustawy ratyfikacyjnej jest odczytywana przez większość wyborców i przez przeciwników Konkordatu, w tym ludzi wierzących, jako potwierdzenie tych wszystkich obaw, które miała rozwiać Deklaracja.

Czymś znamiennym w wypowiedzi posła, nawołującego do włączenia Deklaracji Rządu RP do ustawy ratyfikacyjnej, jest niewątpliwie następujące oświadczenie: „Jednocześnie jednak chcę państwu powiedzieć, że dla mnie ta deklaracja jest niewystarczająca. Nawet, jeśli zapis dotyczący deklaracji zostanie włączony do ustawy, będę głosował przeciwko Konkordatowi. Chciałbym bardzo, żeby miliony ludzi w Polsce miały szansę do przyjęcia Konkordatu z mniejszymi obawami i strachem. Chciałbym także, żeby ustawa, którą i tak państwo przyjmą, w mniejszym stopniu podzieliła polskie społeczeństwo" ${ }^{\circ 1}$.

W związku z oświadczeniem posła P. Ikonowicza, poseł Marian Piłka (AWS) zgłosił formalny wniosek o zamknięcie dyskusji i przejście do głosowania nad opinią Komisji w sprawie ustawy o ratyfikacji Konkordatu ${ }^{62}$.

Poseł Czesław Bielecki, przewodniczący Komisji, zapytał zebranych, czy ów wniosek o zamknięcie listy mówców (do dyskusji zgłosiło się jeszcze siedmiu posłów) zostaje przyjęty; wniosek ten przyjęto.

Pierwszym ze zgłoszonych dyskutantów był poseł Grzegorz Piechowiak (AWS), który krytycznie odniósł się do wypowiedzi posłów SLD: Włodzimierza Konarskiego i Antoniego Kobielusza.

\footnotetext{
59 Biuletyn nr 119/III, 10-11.

60 Tamże, 11.

61 Tamże.

62 Tamże.
} 
Poseł Marian Sołtysiewicz (AWS) zarzucił posłom lewicy, że ich wola dołączenia do ustawy ratyfikacyjnej Deklaracji Rządu RP jest nieszczera, mieli bowiem dużo czasu (w poprzedniej kadencji sejmowej), by przyjąć ustawę ratyfikacyjną wraz z Deklaracją. Dodał jednocześnie, że skoro Konkordat jest zgodny z Konstytucją RP, to nic nie stoi na przeszkodzie, by „uściślić i uwypuklić to, o co nam wszystkim chodzi, w ustawach okołokonkordatowych"63.

Poseł Irena Lipowicz (UW), po sprostowaniu stwierdzenia posła A. Kobielusza o sytuacji mniejszości wyznaniowych (otrzymały stosowne ustawy, wydane po uprzednich umowach zawartych z Państwem), zwróciła uwagę, że tak drastyczne odkładanie ratyfikacji Konkordatu doprowadzi „do trwałego pokrzywdzenia mniejszości wyznaniowych, ponieważ korzystniejsze dla nich regulacje prawne uchwalone w związku z Konkordatem, będą musiały być odrzucone" ${ }^{64}$. Szczególną wymowę można przypisać następującym słowom posłanki: „Przez kunktatorstwo doprowadziliśmy do paradoksalnej sytuacji, w której Kościół Katolicki jest upośledzony w stosunkach prawnych, np. w zakresie małżeństw kanonicznych w porównaniu do mniejszości wyznaniowych. Obecna sytuacja jest dokładnie odwrotna. Mniejszości wyznaniowe w Polsce są przejściowo i ten stan chce usunąć koalicja - bardziej uprzywilejowane niż Kościół Katolicki. Sądzę, że nie jest to państwa intencją. Chcemy doprowadzić do konstytucyjnej równości wyznań" ${ }^{65}$.

Posłanka nie omieszkała wytknąć lewicy brak szczerości w składaniu deklaracji: przez wiele lat ugrupowanie to zapewniało, że Konkordat zostanie ratyfikowany niezwłocznie po otrzymaniu jakiegoś wyjaśnienia, następnie twierdziło, że ratyfikacja zostanie dokonana po uchwaleniu Konstytucji, aktualnie zaś warunkiem po temu nie jest Konstytucja, lecz Deklaracja Rządu RP. Ta ostatnia, dodaje I. Lipowicz, jako wyjaśnienie będzie miała znaczenie dla interpretacji Konkordatu. „Proszę nie wprowadzać w błąd opinii publicznej, że deklaracja nie będzie miała takiego znaczenia. Opinia prof. Langa w tym zakresie jest odosobniona”,

\footnotetext{
63 Tamże, 1-12.

64 Tamże, 12.

65 Tamże.
} 
stwierdziła posłanka Unii Wolności ${ }^{66}$. Dodała, że ,robienie z Deklaracji załącznika do umowy, w sytuacji gdy nie dołączyliśmy załącznika do traktatu z Niemcami oznaczałoby, że nasze zaufanie do Stolicy Apostolskiej jest dużo mniejsze niż zaufanie do państwa niemieckiego mimo naszej skomplikowanej historii" ${ }^{67}$.

Irena Lipowicz poruszyła jeszcze jeden wątek: dotyczący wątpliwości lewicy co do nauki religii w przedszkolach, co stanowi, jak powiedziała, „zasadniczy i fundamentalny punkt sprzeciwu” tej formacji. Jej zdaniem, ustawa ratyfikacyjna już dawno byłaby uchwalona, ,gdyby nie upieranie się ministra Wiatra przy sprzecznej z prawem interpretacji"68.

Poseł Tadeusz Iwiński (SLD) zwięźle wyjaśnił, iż jego wniosek nie dotyczył dodania do Konkordatu jakiegokolwiek załącznika, podobnie jak to zakładała autopoprawka rządu premiera Cimoszewicza, lecz jedynie rozszerzenia zdania ustawy upoważniającego prezydenta do ratyfikacji Konkordatu o stwierdzenie, że Konkordat jest rozumiany w świetle owej Deklaracji ${ }^{69}$.

W wypowiedzi posła Tadeusza Mazowieckiego (UW) znalazły się dwa wątki, które dotyczyły korzystnego statusu kościołów mniejszościowych oraz charakteru Deklaracji Rządu RP, która jedynie potwierdza to, co W rzeczywistości zostało już uregulowane ${ }^{70}$.

Poseł Longin Pastusiak (SLD), wyjaśniając dlaczego jego klub jest za przyjęciem Deklaracji Rządu RP, odwołał się do stwierdzenia Ministra Spraw Zagranicznych, który mówił o znaczeniu tego dokumentu jako „Zawierającego dodatkowe gwarancje praw i wolności obywatelskich"71.

\footnotetext{
66 Tamże.

67 Tamże.

68 Tamże.

69 Tamże, 13.

70 Tamże.
}

71 Chodzi o wystąpienie Bronisława Geremka, Ministra Spraw Zagranicznych, podczas pierwszego czytania w Sejmie (12 grudnia 1997 r.), kiedy to powiedział: „Rząd ze względu na skutki prawne tej deklaracji, jej znaczenie jako dokumentu zawierającego dodatkowe gwarancje praw i wolności obywatelskich, zamierza opublikować jej tekst w Dzienniku Urzędowym [chodzi o Monitor Polski - W.G.] w charakterze załącznika do odrębnego oświadczenia ministra spraw zagranicznych dotyczącego mocy obowiązującej konkordatu”. Kowalczyk 2013, 304. 
Poza tym nawiązał do układu o podstawach normalizacji stosunków między Polską a Niemcami z dnia 7 grudnia 1970 r., kiedy to Bundestag przez dwa lata odmawiał ratyfikacji tego traktatu żądając przyjęcia klauzuli stwierdzającej, że granice mogą być zmienione w drodze pokojowej (dopiero po przyjęciu tej jednostronnej deklaracji układ został ratyfikowany) ${ }^{72}$.

Głos posła Franciszka Adamczyka (AWS) był krótką repliką w stosunku do wypowiedzi Józefa Oleksego, Longina Pastusiaka i Piotra Ikonowicza ${ }^{73}$.

Poseł Czesław Bielecki (AWS), przewodniczący Komisji, wyrażając swoje krytyczne stanowisko wobec lewicy, której musiał się lękać, wyraził pogląd, iż proponowanie inkorporowania Deklaracji Rządu RP do ustawy ratyfikacyjnej jest niewłaściwe, gdyż i tak jest ona obowiązująca; dodatkowe jej podkreślanie jest zbędne. Nawiązując zaś do akcentowania przez ugrupowania lewicowe roli tolerancji, poseł oznajmił, iż zapoznając się z dostarczoną przez posła Tadeusza Iwińskiego ekspertyzą prof. Michała Pietrzaka dostrzegł w niej, zabawne i ponure stwierdzenia, a także wątek rasistowski”. Wymieniony bowiem ekspert zauważa, że ,zastrzeżenia Konkordatu o powoływaniu Polaków na stanowiska biskupów są tak oczywiste współcześnie, że całkowicie zbędne. Powołanie Niemca czy Nigeryjczyka na stanowisko biskupa w Polsce oznaczałoby przecież upadek prestiżu Kościoła”. Fragment ten, zaznaczył parlamentarzysta, stanowi przykład ,przesądów i braku rozumienia wyrazu «tolerancja»"74.

Po wyczerpaniu listy zgłoszonych mówców, przewodniczący obrad zwrócił się o zabranie głosu przez Janusza Stańczyka, podsekretarza stanu w MSZ.

W swoim krótkim wystąpieniu minister stwierdził, że przeprowadzona dyskusja wykazała, jak trudno jest odpolitycznić sprawę w gruncie rzeczy prawną, problem bowiem Deklaracji Rządu RP jest traktowany przez Ministra Spraw Zagranicznych jako problem prawny, a jest on rozstrzygany ,w takim zakresie, na jaki pozwala racjonalne i legalistyczne stosowanie prawa"75. Takiemu charakterowi dokumentu z 15 kwietnia 1997 r., dodał mówca, nieodpowiadaformułazaprezentowanaprzezposła Józefa Oleksego,

72 Biuletyn nr 119/III, 13.

73 Tamże, 14.

74 Tamże.

75 Tamże. 
który zwrócił się z apelem o uznanie wątpliwości osób zgłaszających je wobec Konkordatu. Janusz Stańczyk wyraził przekonanie, że „rząd i minister spraw zagranicznych wypełnia ten standard z dużym zapasem" "76.

Gdy przewodniczący obrad zamierzał poddać pod głosowanie wniosek o skierowanie rządowego projektu ustawy o ratyfikacji Konkordatu do drugiego czytania z akceptacją Komisji, poseł Tadeusz Iwiński zwrócił uwagę, że najpierw należy poddać pod głosowanie poprawkę do projektu ustawy.

Przyjmując tę uwagę, przewodniczący poddał pod głosowanie wniosek zgłoszony przez posła Tadeusza Iwińskiego, by w art. 1 projektu ustawy po wyrazach: „sporządzonego w Warszawie dnia 28 lipca 1993 r.” - kropkę zastąpić przecinkiem i dodać wyrazy: ,tak jak jest on rozumiany w świetle deklaracji rządu Rzeczypospolitej Polskiej z dnia 15 kwietnia 1997 r. zawierającej oświadczenie w celu zapewnienia jasnej wykładni przepisów Konkordatu załączonej do niniejszej ustawy ${ }^{77}$ ".

Za przyjęciem wniosku głosowało ośmiu posłów, dziewiętnastu było przeciwnych, jeden poseł wstrzymał się od głosu. W ten sposób wniosek nie został przyjęty.

Po zgłoszeniu przez posła Tadeusza Iwińskiego wniosku mniejszości (do sprawozdania Komisji) oraz zapowiedzi głosowania nad sprawozdaniem Komisji głos - w sprawie formalnej - zabrał poseł Włodzimierz Konarski (SLD), proponując odłożenie głosowania aż do czasu szczegółowych wyjaśnień Ministra Spraw Zagranicznych, ze względu na rangę umowy. Poseł motywował to tym, że wszyscy powinni mieć czas na zapoznanie się z poszczególnymi opiniami, które zostały doręczone członkom Komisji ${ }^{78}$.

Natomiast wniosek przeciwny złożył poseł Stefan Niesiołowski (AWS), proponując, by głosowanie nad sprawozdaniem Komisji odbyło się natychmiast, wszyscy bowiem wystarczająco zapoznali się z ekspertyzami oraz wysłuchali głosu ministra J. Stańczyka. „Prosiłbym posłów lewicy zaapelował poseł - żeby nie nadużywali naszej anielskiej cierpliwości"79.

$\mathrm{W}$ trybie ad vocem poseł Longin Pastusiak (SLD) zaprzeczył stwierdzeniu posła S. Niesiołowskiego o zapoznaniu się wszystkich

\footnotetext{
76 Tamże.

77 Tamże, 15.

78 Tamże.

79 Tamże.
} 
z ekspertyzami, nie chodzi bowiem o opinie co do zgodności Konkordatu z Konstytucją RP (te opinie są znane), lecz o opinie dotyczące „trybu uchwalenia Konkordatu" $"$.

Po poddaniu pod głosowanie wniosku posła Włodzimierza Konarskiego o przełożenie głosowania nad sprawozdaniem Komisji okazało się, że wniosek upadł, poparło go bowiem tylko siedmiu posłów, dziewiętnastu było przeciwnych, nikt nie wstrzymał się od głosu ${ }^{81}$.

Z kolei przewodniczący zarządził głosowanie nad sprawozdaniem Komisji w następującym brzmieniu: „Sprawozdanie Komisji Spraw Zagranicznych o rządowym projekcie ustawy o ratyfikacji Konkordatu między Stolicą Apostolską a ${ }^{82}$ Rzecząpospolitą Polską. Sejm zgodnie $\mathrm{z}$ art. 36 ust. 2 regulaminu Sejmu na 5. posiedzeniu w dniu 12 grudnia skierował powyższy projekt ustawy do Komisji Spraw Zagranicznych, w celu rozpatrzenia. Komisja Spraw Zagranicznych po rozpatrzeniu tego projektu ustawy na posiedzeniu w dniu 16 grudnia wnosi: Wysoki Sejm uchwalić raczy projekt ustawy z druku $\mathrm{nr} 30$ bez poprawek, z następującym wnioskiem mniejszości...”. „Tu zostanie przytoczony wniosek mniejszości zgłoszony przez posła Iwińskiego"

Za wnioskiem opowiedziało się dwudziestu jeden posłów, trzech było przeciwnych, czterech wstrzymało się od głosu. W ten sposób Komisja przyjęła sprawozdanie. Na posła sprawozdawcę wybrano Irenę Lipowicz $(\mathrm{UW})^{84}$.

Po głosowaniu o wypowiedź w sprawie formalnej prosił poseł Tadeusz Iwiński (SLD). Apelował o bardziej staranne analizowanie dokumentów i ekspertyz na przyszłość, bez względu na to, od kogo pochodzą. Zwrócił się także o to, by w debacie nie stosować argumentów ad hominem oraz o to, by przewodniczący w mniejszym stopniu zajmował się komentowaniem wypowiedzi posłów, a bardziej dbał o przestrzeganie regulaminu.

Z kolei poseł Józef Oleksy (SLD) prosił o wspólne przyczynianie się do zachowania dobrych obyczajów niezależnie od istniejących rozbieżności.

\footnotetext{
80 Tamże.

81 Tamże, 15-16.

82 Powinno być ,i”, zgodnie z formułą przyjętą w tytule Konkordatu.

83 Biuletyn nr 119/III, 16.

84 Tamże.
} 
Zwrócił też uwagę posłowi Stefanowi Niesiołowskiemu (AWS), by nie stosował pogróżek (w formie obawy o wyczerpanie się ,,anielskiej cierpliwości"). Poseł Piotr Ikonowicz (SLD) apelował o nieuogólnianie (przez posła Stefana Niesiołowskiego) sytuacji i traktowanie całej lewicy jako formacji, przed którą trzeba się było „chować do Kościoła”. Poseł Tadeusz Iwiński zapowiedział skierowanie sprawy do Komisji Etyki Poselskiej albo do Komisji Regulaminowej i Spraw Poselskich, albo do obu tych Komisji. Poseł S. Niesiołowski uznał to za nadinterpretację swojej wypowiedzi.

Po tej wymianie zarzutów i pretensji przewodniczący dokonał zamknięcia posiedzenia Komisji ${ }^{85}$.

\section{UWAGI KOŃCOWE}

Gdy po zwycięstwie Akcji Wyborczej Solidarność w wyborach parlamentarnych dnia 21 września 1997 r. procedura ratyfikacyjna Konkordatu została „odblokowana”: 7 listopada 1997 r. Rada Ministrów, kierowana przez premiera Jerzego Buzka, przyjęła nowy projekt ustawy ratyfikacyjnej, a następnie, stosownie do art. 133 ust. 1 pkt 1 i art. 88 ust. 3 Konstytucji RP, skierowała go do Sejmu. Brzmienie tego dokumentu było następujące: „Art. 1. Wyraża się zgodę na dokonanie przez Prezydenta Rzeczypospolitej Polskiej ratyfikacji Konkordatu między Stolicą Apostolską i Rzecząpospolitą Polską, sporządzonego w Warszawie dnia 28 lipca 1993 roku. Art. 2. Ustawa wchodzi w życie po upływie 14 dni od dnia ogłoszenia" ${ }^{\circ 6}$.

Jak już wyżej wspomniano, podczas pierwszego czytania projektu tej ustawy, Sejm skierował go do rozpatrzenia przez sejmową Komisję Spraw Zagranicznych.

Debata tego gremium, poświęcona dwom kwestiom, stała się kolejną okazją do usiłowania dalszego torpedowania przez polityków lewicy, tym razem już finalnego etapu procedury ratyfikacyjnej. Ich świadomość, że stanowią zdecydowaną mniejszość parlamentarną i że los Konkordatu

85 Tamże, 16-17.

86 Ustawa z dnia 8 stycznia 1998 r. o ratyfikacji Konkordatu między Stolicą Apostolską i Rzecząpospolitą Polską, Dz. U. z 1998 r. Nr 12, poz. 42. 
został już przesądzony, bynajmniej nie przeszkadzała im w stawianiu kolejnych przeszkód w celu utrudnienia uchwalenia ustawy ratyfikacyjnej.

W kwestii trybu ratyfikacji Konkordatu posłowie SLD wykazali niczym nieuzasadniony upór w lansowaniu tezy o konieczności zastosowania art. 90 ust. 1 i 2 Ustawy zasadniczej, nie zaś art. 89. Wiązało się to najpierw z niezrozumiałym uznaniem Kościoła Katolickiego za „organizację międzynarodową” lub „organ międzynarodowy”, a następnie z równie błędnym przyjęciem, iż w Konkordacie Rzeczpospolita Polska przekazuje Kościołowi Katolickiemu „kompetencje organów władzy państwowej w niektórych sprawach". W efekcie takich supozycji uchwalenie ustawy ratyfikacyjnej wymagałoby uzyskania większości 2/3 głosów w Sejmie (w obecności co najmniej połowy ustawowej liczby posłów) i tyle samo w Senacie (art. 90 ust. 2 Konstytucji RP).

Zabierający głos w dyskusji posłowie SLD, powołując się na niektóre zamówione przez siebie ekspertyzy, wyrażali przekonanie, że na mocy Konkordatu Państwo polskie przekazuje „organizacji międzynarodowej”, którą jest Kościół Katolicki, niektóre swoje kompetencje (m.in. gdy chodzi o małżeństwo kanoniczne wywierające skutki, jakie pociąga za sobą zawarcie małżeństwa zgodnie z prawem polskim, art. 10).

W swojej wypowiedzi wygłoszonej podczas pierwszego czytania projektu ustawy ratyfikacyjnej (12 grudnia 1997 r.) Bronisław Geremek, Minister Spraw Zagranicznych, podkreślił, że „Konkordat w żadnym stopniu nie uszczupla zakresu suwerenności Państwa polskiego w dziedzinie stosowania prawa [...] i nie przewiduje podporządkowania prawa polskiego normom prawa kanonicznego" $"$.

Nie bez znaczenia było także przytoczone już stwierdzenie wiceministra Janusza Stańczyka, wypowiedziane podczas obrad Komisji, iż w doktrynie prawa międzynarodowego $\mathrm{i}$ w praktyce międzynarodowej nie ma wątpliwości, że Stolica Apostolska nie ma statusu organizacji międzynarodowej ani organu międzynarodowego.

Bardziej „złożona” okazała się druga kwestia dyskutowana podczas posiedzenia sejmowej Komisji Spraw Zagranicznych, a więc dotycząca

87 Pierwsze czytanie rządowego projektu ustawy o ratyfikacji konkordatu między Stolicą Apostolską i Rzecząpospolitą Polską przez ministra spraw zagranicznych Bronisława Geremka. Kowalczyk 2013, 304. 
dołączenia do ustawy ratyfikacyjnej wzmianki o Deklaracji Rządu RP premiera Włodzimierza Cimoszewicza z dnia 15 kwietnia 1997 r. Przedstawiciele lewicy, domagając się dodania do ustawy ratyfikacyjnej wzmianki o tym, że chodzi o ratyfikację Konkordatu ,tak jak jest on rozumiany w świetle Deklaracji rządu Rzeczypospolitej Polskiej z dnia 15 kwietnia 1997 r. zawierającej oświadczenie, w celu zapewnienia jasnej wykładni przepisów Konkordatu, załączonej do niniejszej ustawy”88, chcieli w ten sposób „zabezpieczyć się" przed jakąkolwiek inną interpretacją określonych przepisów konkordatowych niż ta, która została przyjęta w Deklaracji Rządu RP. W odstąpieniu od tego zamysłu przez lewicę nie pomagało ani przypomnienie wcześniejszego, miarodajnego wyjaśnienia (podczas pierwszego czytania projektu ustawy ratyfikacyjnej) ministra Bronisława Geremka, iż Deklaracja Rządu RP stanowi „kontekst interpretacyjny dla traktatu” ani szersze wyjaśnienie wiceministra Janusza Stańczyka (na posiedzeniu Komisji) sprowadzające się do tego, że ów dokument „niczego nie ujmuje i niczego nie dodaje” w stosunku do postanowień Konkordatu. Nie przełamały też uporu posłów lewicy słowa wymienionego podsekretarza stanu wyjaśniające status tego typu dokumentu regulowany prawem międzynarodowym (Konwencją Wiedeńską o prawie traktatów).

Gdy mowa o treści owej Deklaracji, to należy zdecydowanie stwierdzić, że stanowi ona wyłącznie parafrazę dyspozycji konkordatowych, niczego w stosunku do nich nie wnosząc. Nie ulega wątpliwości, że dokument ten w ogóle nie był potrzebny: wystarczyło uważnie czytać przepisy umowy dwustronnej.

Demagogicznie wybrzmiewały głosy posłów lewicy żądających zamieszczenia wzmianki o Deklaracji Rządu RP w ustawie ratyfikacyjnej, a wręcz fałszywą nutę można było wyczuć w przytoczonym wyżej stwierdzeniu jednego z nich: „Stolica Apostolska nie wyrażając sprzeciwu na deklarację rządu polskiego pośrednio uznała, że warto coś w Konkordacie uściślić i wyjaśnić". Za trafną należy uznać konstatację ministra J. Stańczyka, że przeprowadzona dyskusja wykazała, jak trudno jest odpolitycznić sprawę w gruncie rzeczy prawną.

Drugie czytanie w Sejmie rządowego projektu ustawy ratyfikacyjnej odbyło się 8 stycznia 1998 r. Przyjęty przez Komisję Spraw Zagranicznych

88 Biuletyn nr 119/III, 5. 
projekt przedstawiła poseł Irena Lipowicz. Wyjaśniając m.in. charakter Deklaracji Rządu RP, która nie może towarzyszyć ustawie, Izba nie przyjęła wniosku SLD o dołączenie do ustawy tej Deklaracji.

Tego samego dnia miało miejsce trzecie czytanie projektu ustawy, na który głos oddało 273 posłów; przeciw było 160, a 2 głosy były wstrzymujące ${ }^{89}$.

\section{BIBLIOGRAFIA}

Góralski, Wojciech. 1998a. Konkordat polski 1993. Od podpisania do ratyfikacji. Warszawa: Wydawnictwo Akademii Teologii Katolickiej.

Góralski, Wojciech. 1998b. „Nowy klimat wokół konkordatu”. Niedziela 41: 20.

Kowalczyk, Józef. 2013. Konkordat między Stolica Apostolska i Rzeczapospolita Polska 1993/1998. Uktad między dwoma podmiotami prawa międzynarodowego na tle ksztaltowania się relacji pomiędzy Kościolem katolickim i Państwem polskim w okresie I i II Rzeczypospolitej, w warunkach totalitaryzmu $i$ w III Rzeczypospolitej. Płock: Płocki Instytut Wydawniczy.

Krukowski, Józef. 1999. Konkordat polski. Znaczenie i realizacja. Lublin: Oficyna Wydawnicza VERBA.

Krukowski, Józef. 2000. Kościót i państwo. Podstawy relacji prawnych. Lublin: Redakcja Wydawnictw Katolickiego Uniwersytetu Lubelskiego.

Krukowski, Józef. 2008. „Realizacja Konkordatu z 1993 r. w polskim porządku prawnym". W: Konkordat polski w 10 lat po ratyfikacji. Materiaty z konferencji, red. Józef Wroceński, Helena Pietrzak, 97-129. Warszawa: Wydawnictwo Uniwersytetu Kardynała Stefana Wyszyńskiego.

Olejarz, Tomasz. 2009. „Podmiotowość Stolicy Apostolskiej w stosunkach międzynarodowych”. Annales Universitatis Mariae Curie-Skłodowska Sectio K 16: 67-94.

Rokita, Jan. 1998. „Realizacja postanowień Konkordatu 1993 w kontekście polskiego prawodawstwa państwowego". W: Konkordat polski 1993. Dar i zadanie dla Kościoła i Polski, red. Jan Dyduch, 41-58. Kraków: Wydawnictwo św. Stanisława BM.

Wisłocki, Jerzy. 1993. Konkordat polski 1993. Tak czy nie? Poznań: Kantor Wydawniczy SAWW.

89 Kowalczyk 2013, 178. 
Włodarczyk, Tadeusz. 1986. Konkordaty. Zarys historii ze szczególnym uwzględnieniem XX wieku, wyd. 2. Warszawa: Państwowe Wydawnictwo Naukowe.

Wysoczański, Wiktor. 2008. „Wpływ Konkordatu z 1993 r. na sytuację prawną kościołów i innych związków wyznaniowych mniejszościowych". W: Konkordat polski w 10 lat po ratyfikacji. Materiaty z konferencji, red. Józef Wroceński, Helena Pietrzak, 69-85. Warszawa: Wydawnictwo Uniwersytetu Kardynała Stefana Wyszyńskiego. 
